\title{
Soft adventure motivation: an exploratory study of hiking tourism
}

\author{
Bernhard Fabian Bichler and Mike Peters
}

\begin{abstract}
Purpose - Adventure activities have become the core products of many tourism destinations. Hiking, which is known to be a soft adventure activity, represents an especially important product for many tourism destinations around the globe and in the European Alps. However, little research has explored hikers' underlying motivation and experiences, which are expected to differ from the hard adventure context, as mountain hiking provides a low risk, but high immersion. This paper aims to determine and explore the underlying dimensions and dynamics of mountain hikers' soft adventure motivation (SAM).

Design/methodology/approach - A concurrent mixed-method design that builds on a quantitative survey $(N=379)$ and qualitative interviews $(N=14)$ was used to explore SAM factors. This study combined exploratory factor analysis and regression analysis with semi-structured interviews and template analysis.
\end{abstract}

Findings - The quantitative results provide six SAM factors and emphasize that "relaxation," "socializing" and "discovery" contribute to hiking satisfaction, while "recognition" has adverse effects. By triangulating these findings with hikers' experiences, this study underlines the associated recreational meaning of hiking and provides an in-depth qualitative discussion of SAM factors and the subordinate role of "recognition."

Originality/value - The contribution of this paper is a refined understanding of SAM in the hiking context by emphasizing the recreational meaning of mountain hiking. As a result, this study adds an important missing link to previous outdoor tourism and leisure studies by showing the special composition and dynamics of SAM. The findings also support the creation of tailor-made touristic products.

Keywords Motivation, Adventure tourism, Soft adventure, Hiking

Paper type Research paper

软”探险活动的动机: 徒步旅游的探索性研究

㸴究目的：探险活动已经成为许多旅游目的地的核心产品。其中徒步旅行被认作为一种“轻松”探险活动 并且代表着全球众多旅游目的地及欧洲阿尔卑斯山的重要产品。然而, 很少有硏究探索远足者的潜在动机 和经验, 由于徒步远足的风险较低, 但参与感高, 因此预计于艰苦的冒险环境有所不同。因此, 本文确定并 探索了山地徒步者“轻松”冒险动机的潜在维度和动力。

设计/方法/方法 : 采用基于定量调查 $(N=379$ )和定性访谈 $(N=14)$ 的并行混合方法设计来探索 $S A M$ 因素。

因此, 我们将探索性因子分析和回归分析与牛结构化访谈和模板分析相结合。

结果：定量结果提供了6个SAM因素, 并强调“放松”、“社交”和“发现”有助于提升满意度, 而“认知”则有负 面影响。通过将这些发现与徒步旅行者的经历进行三角分析, 我们强调了徒步旅行的相关娱乐意义, 并对 SAM因素和“识别”的从属作用进行了深入的定性讨论。

原创性/价值：本文的贡献在于通过强调登山的休闲意义, 对徒步情景下的SAM进行了精细化的理解。因 此, 我们通过展示 $S A M$ 的特殊组成和动态, 为之前的户外旅游和休闲研究添加了一个重要的缺失环节。最 后, 㸴究结果支持了定制旅游产品的创造。

关键字: 探险旅游, 动机, 软探险, 徒步

文章类型: 研究论文

\section{Motivación de aventura de baja dificultad: Un estudio exploratorio del turismo de senderismo}

Propósito : Las actividades de aventura se han convertido en uno de los productos principales de muchos destinos turísticos, especialmente el senderismo, una actividad de aventura de baja dificultad que representa un producto importante para muchos destinos turísticos alrededor del mundo y en los Alpes europeos. Sin embargo, pocas investigaciones han estudiado la motivación y las experiencias
Bernhard Fabian Bichler and Mike Peters are both based at the Department of Strategic Management, Marketing and Tourism, University of Innsbruck, Innsbruck, Austria.

Received 2 October 2019 Revised 20 March 2020 3 June 2020

Accepted 6 July 2020

(C) Bernhard Fabian Bichler and Mike Peters. Published by Emerald Publishing Limited. This article is published under the Creative Commons Attribution (CC BY 4.0) licence. Anyone may reproduce, distribute, translate and create derivative works of this article (for both commercial and noncommercial purposes), subject to full attribution to the original publication and authors. The full terms of this licence may be seen at http://creativecommons. org/licences/by/4.0/legalcode

The authors would like to thank Katharina Scherer and Carmen Schönegger in her assistance in collecting the data. 
subyacentes de los excursionistas, las cuales se espera que difieran del contexto de aventura de alta dificultad, ya que el senderismo de montaña proporciona un bajo riesgo pero una alta inmersión. Por lo tanto, este documento determina y examina las dimensiones y dinámicas subyacentes de la motivación de aventura de baja dificultad (SAM, por sus siglas en inglés) de los excursionistas de montaña.

Diseño/metodología/enfoque : Se utilizó un diseño de método mixto concurrente que se basa en una encuesta cuantitativa $(N=379)$ y entrevistas cualitativas $(N=14)$ para explorar los factores de SAM. De este modo, se combinó análisis factorial exploratorio y análisis de regresión con entrevistas semiestructuradas y análisis de plantillas.

Resultados : Los resultados cuantitativos aportan seis factores de SAM y enfatizan que la "relajación", la "socialización" y el "descubrimiento" contribuyen a la satisfacción del senderismo, mientras que el "reconocimiento" tiene efectos adversos. Al relacionar estos hallazgos con las experiencias de los excursionistas se destaca el significado recreativo asociado al senderismo y se brinda una discusión cualitativa profunda de los factores de SAM y el papel subordinado del "reconocimiento".

Originalidad/valor : La contribución de este artículo es una comprensión refinada de la SAM en el contexto de senderismo al enfatizar el significado recreativo del senderismo de montaña. De este modo, se suma un importante eslabón perdido a los estudios anteriores de turismo al aire libre y de ocio al mostrar la composición y dinámica especial de la SAM. Por último, los resultados respaldan la creación de productos turísticos hechos a la medida de las preferencias de los turistas.

Palabras clave : Turismo de aventura Motivación, Aventura de baja dificultad, Senderismo

Tipo de papel : Trabajo de investigación

\section{Introduction}

Hiking is a popular recreational activity that provides positive impacts on health and wellbeing and constitutes a core tourism product around the world (UNWTO, 2019; Gross and Sand, 2019). Many destinations and organizations offer specialized products which include hiking and related activities such as walking, long-distance hiking or mountaineering (Muhar et al., 2007; Mehmetoglu and Normann, 2013). In addition to the benefits of outdoor activities such as hiking for the general well-being (Abraham et al., 2010; Sand et al., 2019), the UNWTO also emphasized its contribution "to better engage with local people, nature and culture" (2019, p. 4). From a destination management perspective, hiking is a unique product, as it benefits rural development by enabling all-year-round tourism and as a result helps to mitigate off-peak seasons (Kastenholz and Rodriguez, 2007; Wall-Reinius and Bäck, 2011). Additionally, as a tourist activity hiking, shows less negative environmental impact compared to other intrusive activities (Thongdejsri and Nitivattananon, 2019). This is reinforced by permitting several day tours and offering various options with corresponding services along the route contributing to sustainable tourism (Raya et al., 2018). In contrast to mountaineering, hiking is commonly understood as a soft adventure activity that includes fewer physical challenges and risks to participants (Pomfret, 2006). For some, hiking represents a pure sporting activity, while others favor it as a social event, an immersive natural experience or as an amalgamation of these aspects (Den Breejen, 2007; Pomfret, 2006, 2011; Rodrigues et al., 2010).

While people hike all over the world, the European Alps offer an especially appealing environment for mountain hiking, which is why many destinations concentrate on hiking as their core product in the summer season (Tirol Werbung, 2018). In light of the current rise of adventure tourism literature (Gross and Sand, 2019; Varley and Semple, 2015), it is particularly interesting to explore the motivations and arising experiences, which drive mountain hiker's participation. In tourism and leisure research, many studies focused on motivation-based approaches to segment outdoor sports participants (Dolnicar, 2004; Albayrak and Caber, 2018; Lee et al., 2004; Park and Yoon, 2009; Hallmann et al., 2012). However, few studies focused on soft adventures (Pomfret and Bramwell, 2016; Rantala et al., 2018), only Løvoll (2019) explored hiking as a soft adventure activity, although from a narrow glacier hiking context. This study aims to provide an improved understanding of mountain hikers' soft adventure motivation (SAM) and discusses it in the light of associated experiences. As this is a new and not yet established field, we use a concurrent mixed 
method design (Teddlie and Yu, 2007), which builds on a quantitative survey $(n=379)$ and a qualitative interview $(n=14)$ phase. We identify the underlying SAM factors of mountain hikers and explore the relationship between SAM and satisfaction, as the latter is perceived key for return (Oh, 1999; Kozak, 2001). This paper helps to conceptualize the underlying motivations of mountain hikers and discusses the recreational meaning of mountain hiking. In contrast to hard adventure literature, this paper highlights an adapted set of SAM factors and thereby contributes to the current literature on soft adventure tourism (Gross and Sand, 2019). Finally, we relate these findings with hikers' satisfaction and provide implications for the creation of tailor-made hiking products.

\section{Theoretical background}

\subsection{The role of soft adventures for adventure tourism}

Defining adventure tourism is difficult, as it is a function of subjective and personal criteria, rather than captured by a uniform definition of adventure (Weber, 2001; Kerr and Mackenzie, 2012). Pomfret (2006) offered a classification of hard and soft adventure that is distinguished by the amount of risk involved. In this vein, Varley and Semple (2015, p. 78) highlighted that soft or slow adventure represents a concept based on "feeling, sensing and investing in place, community, belonging, sociality, as well as traditions over time and in nature".

Until recently, the majority of quantitative studies have focused on the hard adventure context and examined the motivation factors that lead to participation in risky sporting activities, e.g. skydiving or kayaking (Buckley, 2012; Pomfret, 2006). Few empirical insights exist for soft adventures (Den Breejen, 2007; Pomfret and Bramwell, 2016; Rantala et al., 2018). Previous research on hiking only explored hikers' characteristics (Kastenholz and Rodriguez, 2007; Kim et al., 2015) or critical behavioral features, such as length of stay, pursued activities, organization mode or travel mode (Muhar et al., 2007). While previous studies explained hard adventures (Gross and Sand, 2019), the academic knowledge around SAM is still at an infant stage, especially in the hiking context (Løvoll, 2019). However, understanding the reasons why people participate in outdoor activities such as mountain hiking depends on discovering the underlying motivations and experiences leading to satisfaction and thereby future engagement.

More recent adventure studies focused extensively on the rafting context (Albayrak and Caber, 2018; Beckman et al., 2017; Fluker and Turner, 2000) and provided comparisons between multiple risky sporting activities such as canoeing, rafting, kayaking and climbing (Ewert et al., 2013). Albayrak and Caber (2018) found that rafting tourists are mostly driven by the desire to improve both mental and physical skills and abilities to master challenges. This is consistent with previous findings of Ewert et al. (2013), who showed the importance of skills/challenges, social interactions and self-identity for hard adventures. Similarly, the literature on hard adventures used edgework/risk theory (Lyng, 1990; Walle, 1997) to explore the voluntary and calculated pushing of personal limits toward the "edge," which results in intense feelings by extending emotional, physical and mental limits (Pomfret and Bramwell, 2016; Schumacher, 2016). Gross and Sand (2019) noticing a lack of theory for the general adventure field, also confirmed Varley and Semple (2015), calling for an extension of the adventure tourism understanding beyond risk, thrill and edgework. This is especially important as risk is not central for the soft adventure context (Pomfret, 2006) and factors such as new insights, desire to relax from everyday life, develop and improve skills and new knowledge are more important (Weber, 2001). Special focus should be paid to the factor of developing personal limits, experiencing a different setting and getting involved in extensive natural settings, as they are essential for the soft adventure context (Pomfret, 2006). Taking into consideration the trends toward the softening of adventure tourism (Eilzer and Harms, 2019; Rantala et al., 2018) and its regional economic impacts (Müller, 2019), it becomes particularly important to reveal mountain hikers' SAM. 


\subsection{Relationship between motivation and hiking satisfaction}

In tourism and leisure research, motivation is an important concept to understand why people go on holiday or participate in holiday activities (Ryan and Glendon, 1998). Building on the long-lasting tradition of motivation studies in the tourism and leisure field, the push and pull theory that explores internal and external motivation has been frequently used (Dann, 1977; Uysal and Jurowski, 1994). Another starting point is the expectancy theory of Vroom (1964) that focuses on the process of motivation and attempts to clarify how people decide between various behavioral options. The grassroots of this theory are formed by expectancy, instrumentality and valence, which results in the motivational force. Previous work summarized that expectancy relates to the expectation that effort will result in a good performance and instrumentality refers to the more effort, the higher the likelihood to achieve the outcome. Finally, it summarizes that valence captures the value placed on the rewards (Chiang et al., 2008; Kiatkawsin and Han, 2017).

For this study, we adopt the definition of Lounsbury and Polik (1992) and conceptualize hiking satisfaction as the positive affective state arising from the appraisal of one's hiking and hiking-related experiences. This is also consistent with previous studies, which state that pleasing, relaxing or exciting experiences result in satisfaction and boring or frustrating activities lead to the contrary (Chhetri et al., 2004). The motivation-satisfaction relationship was highlighted by a series of previous studies: Beggs and Elkins (2010) showed that competency/mastery is essential for leisure satisfaction and participation, while Thomas and Butts (1997) stressed the relationship of psychological/intellectual factors. Additionally, Chen (2007) found a significant relationship between motivation and leisure satisfaction, but could not validate this relationship in a later study (Chen et al., 2013). In summary, previous studies provide a scattered picture of the motivation-satisfaction relationship and as a result, we conclude that the experience of a satisfying hike is related to certain motivational needs (Beard and Ragheb, 1983) but also potentially mediated by other variables such as the consumption experience or the degree of leisure involvement (Chen et al., 2013). As we showed that motivation factors are related to needs, we followed Lounsbury and Polik (1992) and theorized that gratification of motivational needs is related to hiking satisfaction. Therefore, we formed our satisfaction construct based on the work of Duda and Nicholls (1992) and Gould et al. (2008), which addresses gratification and satisfaction. Additionally, we treated satisfaction as a key antecedent to influence tourists' post-trip behavior (Kozak, 2001; Leri and Theodoridis, 2019).

\subsection{Development of hypothesis and research question}

The previous sections explored the differences and activity-specific characteristics of hard and soft adventure and shed light on the motivation-satisfaction relationship. Based on the literature review and previous studies (Gross and Sand, 2019; Weber, 2001; Pomfret, 2006), we developed hypothesis $\mathrm{H} 1$ to $\mathrm{H} 6$. For example, research on long-distance walkers showed that they are strongly driven by the desire to get away from the demands at home (Den Breejen, 2007) and are less motivated by recognition (Brämer, 2008; Ortner et al., 2020), which was also stressed by Ewert (1985) in the more risky climbing context. Therefore, we derive the following hypothesis for the mountain hiking context:

\section{H1. "Relaxation" is positively related to hiking satisfaction \\ H2. "Recognition" is negatively related to hiking satisfaction}

Furthermore, Pomfret and Bramwell (2016) highlighted that socializing and challenge represent important pull factors for tourists. This is supported by other research, which underlines the importance of socializing for soft adventures (Varley and Semple, 2015) and the fact that a certain threshold of challenge is acquired to achieve flow, which positively relates to the hiking experience (Csikszentmihalyi, 1990; Wöran and Arnberger, 2012).

PAGE 476 | TOURISM REVIEW | VOL. 76 NO. 22021 
Additionally, Beggs and Elkins (2010) confirmed the central role of mastery for leisure satisfaction. Therefore, we develop the following hypothesis:

H3. "Challenge" is positively related to hiking satisfaction

H4. "Socializing" is positively related to hiking satisfaction

Finally, Ewert (1985) showed the role of creativity and discovery for the mountaineering context, which was also supported by Weber (2001), emphasizing the importance of new insights, skill development and new knowledge. Also, Thomas and Butts (1997) stressed the role of intellectual stimulation for leisure satisfaction. Therefore, we derive the following hypothesis:

H5. "Creativity" is positively related to hiking satisfaction

H6. "Discovery" is positively related to hiking satisfaction

As our concurrent mixed method design (Teddlie and Yu, 2007) also involves a qualitative phase, we define the following overall research questions:

$R Q$. What drives motivation, experiences and satisfaction in the hiking context?

Combing qualitative and quantitative methods (Teddlie and Yu, 2007) helps us to provide a deeper discussion of the quantitative findings. Additionally, a better understanding of hikers' SAM factors also requires a qualitative lens to better account for the resulting experiences.

\section{Empirical study}

As previous studies have emphasized the value of mixed-method research for producing plausible, insightful and relevant results (Watson, 1997), we follow Teddlie and Yu (2007) and use a concurrent mixed-method approach. This approach combines a quantitative and qualitative phase to provide a clearer picture of the quantitative data (Onwuegbuzie and Teddlie, 2003). We assess the SAM factors in the quantitative phase and synthesize them with the qualitative results in the discussion phase.

The quantitative data was gathered using an online questionnaire $(n=379)$ which was carried out in spring 2018 in Germany, Austria and Italy. Data acquisition was supported by national mountain sports and hiking associations which hosted the online questionnaire on their websites for a consecutive period of four weeks. The sample includes a larger share of male participants $(66 \%)$ and participants were on average 43 years old, with a minimum of 16 years and a maximum of 83 years. Participants' characteristics are highlighted in Table 1.

To gather the qualitative data, we emulated the methods used by Teddlie and Yu (2007) and used purposive sampling as well. In total, 14 interviews (see Table 1 and Appendix for detailed information) were conducted, asking people about their motivations and

\section{Table 1 Sample description}

\begin{tabular}{ccc} 
Characteristics & Quantitative phase & Qualitative phase \\
\hline Gender of the participants (in \%) & & \\
Female & 34.0 & 64.3 \\
Male & 66.0 & 37.7 \\
Age of participants & $43.1(\mathrm{SD}=14.2)$ & $35.6(\mathrm{SD}=9.7)$ \\
Experience levels (in \%) & 13.2 & 21.4 \\
Less experienced & 49.1 & 71.4 \\
Medium experienced & 37.7 & 7.1
\end{tabular}


experiences. In particular, we asked interviewees to tell us about a typical hike, starting from the preparation, to the return home and to describe their motivation to go hiking. Additionally, we asked the interviewees to describe their experiences while hiking and incidents that increase/decrease satisfaction.

The countries Italy (48.8\%), Germany (26.1\%) and Austria (25.1\%) were chosen for the quantitative phase and offer an interesting context for several reasons. Outdoor sports such as hiking, biking and climbing play a vital role in the summer tourism of these countries. In the past few years, hiking transformed into a modern and appealing activity and many destinations and hospitality businesses offer specialized products and services for it (Wanderhotels, 2019; Tirol Werbung, 2018). The hiking trails are well maintained and marked and the long-distance paths also connect destinations.

\subsection{Measurements}

Previous studies developed several instruments to measure motivation as a multidimensional construct. A prominent instrument is the leisure motivation scale by Beard and Ragheb (1983), which was later adapted to the tourism context by Ryan and Glendon (1998). For the leisure context, Ewert (1985) adapted several constructs from Crandall (1980) to measure motivation in the leisure mountaineering context. While the measurements for the tourism context focus on intellectual, social, competence-mastery and stimulus-avoidance dimensions (Beard and Ragheb, 1983; Ryan and Glendon, 1998), Ewert (1985) focused on the importance of challenge/risk, catharsis, recognition and creativity in the sports context. For this study, all items were tailored from previous literature and are based on the holiday motivation scale by Ryan and Glendon (1998) and the holiday motive statements of Ewert (1985). As the literature review highlighted the special characteristics of soft adventures (for a recent review see Gross and Sand, 2019), we used a combination of both scales to account for the unique dynamics of the soft adventure context (Table 2). This synthesis of the holiday motivation scale (Ryan and Glendon, 1998)

Table 2 Adapted measure from the literature

\begin{tabular}{|c|c|c|}
\hline Original dimensions & Items & Source \\
\hline Relax & $\begin{array}{l}\text { To relax mentally } \\
\text { To get away from it all } \\
\text { To relax physically }\end{array}$ & Ryan and Glendon (1998) \\
\hline Recognition & $\begin{array}{l}\text { To show others I can do it } \\
\text { To be recognized } \\
\text { To be known }\end{array}$ & Ewert (1985) \\
\hline Challenge & $\begin{array}{l}\text { To develop my abilities } \\
\text { To increase my knowledge } \\
\text { To take on new challenges }\end{array}$ & Pomfret and Bramwell (2016) \\
\hline Social & $\begin{array}{l}\text { To be with others } \\
\text { To build friendships } \\
\text { To have a good time with friends }\end{array}$ & Ryan and Glendon (1998) \\
\hline Creativity & $\begin{array}{l}\text { To foster my creativity } \\
\text { To think }{ }^{a} \\
\text { To use my imagination }\end{array}$ & $\begin{array}{l}\text { Ewert (1985) } \\
\text { Pomfret and Bramwell (2016) }\end{array}$ \\
\hline Control & $\begin{array}{l}\text { To develop my decision-making skills }{ }^{a} \\
\text { To gain control }\end{array}$ & Ewert (1985) \\
\hline Discovery & $\begin{array}{l}\text { To view new places and things } \\
\text { To have an adventure } \\
\text { To view the scenery } \\
\text { To enjoy the wilderness }{ }^{a}\end{array}$ & $\begin{array}{l}\text { Ryan and Glendon (1998) } \\
\text { Ewert (1985) }\end{array}$ \\
\hline Satisfaction & $\begin{array}{l}\text { I usually have fun going hiking } \\
\text { Hiking provides me a profound sense of gratification } \\
\text { I usually enjoy playing sports }\end{array}$ & Gould et al. (2008) and Duda and Nicholls (1992) \\
\hline
\end{tabular}


and the sport-specific measurements (Ewert, 1985; Pomfret and Bramwell, 2016) enabled a better recognition of the factors that relate to recognition/self-image, creativity and the role of discovering.

Hiking satisfaction was used as a dependent variable to measure the experience of a satisfying hike (Lounsbury and Polik, 1992). We combined three items from previous literature to measure hiking satisfaction (Gould et al., 2008; Duda and Nicholls, 1992). In total, seven constructs explored motivation (Ryan and Glendon, 1998; Ewert, 1985) and one construct satisfaction (Duda and Nicholls, 1992; Gould et al., 2008). All constructs were measured on a Likert scale, ranging from 1 (= totally disagree) to 7 (= totally agree). Furthermore, data such as country of origin and self-evaluated experience levels were surveyed.

\subsection{Data analysis}

The data was analyzed in three steps. For the quantitative phase, all items were subject to an exploratory factor analysis (EFA) that helped to reduce the number of items and led to the identification of underlying factors. Varimax rotation and an Eigenvalue of 1.0 was used as the extraction threshold, while factors that exceeded a minimum of 0.60 were retained (Hair, 2010). To determine the effects of the identified SAM factors on hiking satisfaction, we used a set of multiple regression analyses. Multicollinearity was not an issue for the data as VIF were below 3 (Hair, 2010). All statistical computations were performed by using IBM SPSS 25.

For the qualitative phase, interviews were analyzed by using template analysis (King et al., 2019), which represents an approach to construct an initial coding template from a priori codes and refine and revise it with inductive codes until it captures the full meaning. In this sense, the qualitative data led to a deeper understanding of the underlying themes, which are defined as 'recurrent and distinctive features of participants' accounts, characterizing particular perceptions and/or experiences, which the researcher sees as relevant to the research question" (King et al., 2019, p. 200). This process was supported by the qualitative data analysis software MAXQDA, which allows assigning codes to text and further qualitative analysis (MAXQDA, 2020).

\section{Results}

As we used a concurrent mixed method design (Teddlie and Yu, 2007), the following section presents the quantitative findings and the synthesis is directly carried out at the discussion stage (Creswell and Plano Clark, 2011; Doyle et al., 2009). To explore the relationships among the SAM dimensions, we used exploratory factor analysis. Both the Kaiser-Meyer-Olkin (KMO) measure of sampling adequacy (0.837) and the Bartlett test of sphericity $\left(3,451.315^{* * *}\right)$ indicated the suitability of EFA. Moreover, Cronbach's alpha was used to assess internal validity and ranged between 0.633 and 0.847 . EFA lead to the identification of six motivation factors that explained $68.20 \%$ of the variance (Table 3 ). However, four items ("to enjoy the wilderness," "to gain control over others," "to think" and "to develop my decision-making skills") were dropped due to low factor loadings (Table 2). The six factors were labeled "relaxation," "recognition," "challenge," "socializing," "creativity" and "discovery," according to the underlying motives. Common method variance was not an issue for the data (Podsakoff et al., 2003), as no single factor emerged and the first factor only explained $27.90 \%$ of the variance.

Average factor means were calculated to assess the relative importance of the factors (Table 3). The results show that the vital factors for mountain hikers were "discovery" ( $M=$ $5.85, S D=0.95)$ and relaxation $(M=5.72, S D=1.19)$. The latter emphasizes mountain hikers' pursuit of mental and physical time-outs that support alienation from everyday life. Another important motivation factor was "socializing" ( $M=4.82, S D=1.31)$, which includes 
Table 3 Exploratory factor analysis

\begin{tabular}{|c|c|c|c|c|c|c|}
\hline Items & Relaxation & Recognition & Challenge & Socializing & Creativity & Discovery \\
\hline To relax mentally & 0.837 & & & & & \\
\hline To get away from it all & 0.795 & & & & & \\
\hline To relax physically & 0.742 & & & & & \\
\hline To show others I can do it & & 0.869 & & & & \\
\hline To be recognized & & 0.863 & & & & \\
\hline To be known & & 0.779 & & & & \\
\hline To develop my abilities & & & 0.843 & & & \\
\hline To increase my knowledge & & & 0.822 & & & \\
\hline To take on new challenges & & & 0.642 & & & \\
\hline To be with others & & & & 0.870 & & \\
\hline To build friendships & & & & 0.777 & & \\
\hline To have a good time with friends & & & & 0.739 & & \\
\hline To foster my creativity & & & & & 0.796 & \\
\hline To use my imagination & & & & & 0.718 & \\
\hline To view new places and things & & & & & & 0.751 \\
\hline To have an adventure & & & & & & 0.667 \\
\hline To view the scenery & & & & & & 0.602 \\
\hline Variance explained (\%) & 27.90 & 13.95 & 9.58 & 6.83 & 5.10 & 4.84 \\
\hline Mean (SD) & $5.72(1.19)$ & $2.10(1.28)$ & $4.29(1.56)$ & $4.82(1.31)$ & $4.26(1.50)$ & $5.85(0.95)$ \\
\hline Cronbach's alpha & 0.798 & 0.828 & 0.847 & 0.750 & 0.727 & 0.633 \\
\hline
\end{tabular}

time spending with family members and friends. "Challenge" $(\mathrm{M}=4.29, \mathrm{SD}=1.56)$ represented the desire to develop and improve existing abilities and skills. Also, "creativity" $(\mathrm{M}=4.26, \mathrm{SD}=1.50)$ was an essential factor for the participants who perceived hiking to foster creativity. The findings demonstrate that "recognition," which refers to social appreciation and recognition from others, was of least importance for the participants $(\mathrm{M}=$ 2.10, SD = 1.28).

\subsection{Regression analysis}

To analyze the SAM-satisfaction relationship, we used a set of multiple regression analyses, based on factor means. The first model (Table 4) shows the main effects of identified SAM factors on hiking satisfaction and yields an $R^{2}$ value of $0.357(F=34.368, p<0.001)$. The second model introduces an additional set of variables and yields an $R^{2}$ value of $0.435(\mathrm{~F}=$ 31.524, $p<0.001)$. Positive and significant effects were found for "relaxation" $(\beta=0.279$;

Table 4 Results of multiple regression analysis

\begin{tabular}{|c|c|c|}
\hline Hiking satisfaction & Model 1 & Model 2 \\
\hline Constant & $2.912^{* * *}$ & $2.442^{* * *}$ \\
\hline Relaxation & $0.309^{* * *}$ & $0.279^{* * *}$ \\
\hline Recognition & $-0.087^{* *}$ & $-0.079^{*}$ \\
\hline Challenge & $0.065^{*}$ & 0.045 \\
\hline Socializing & 0.039 & $0.073^{*}$ \\
\hline Creativity & -0.018 & -0.011 \\
\hline Discovery & $0.216^{* * *}$ & $0.177^{* * *}$ \\
\hline Experience level & & $0.331^{* * *}$ \\
\hline Austria ${ }^{a}$ & & -0.169 \\
\hline Germany ${ }^{a}$ & & -0.155 \\
\hline F-value & $34.368^{* * *}$ & $31.524^{* * *}$ \\
\hline Adjusted $R^{2}$ & 0.346 & 0.421 \\
\hline$R^{2}$ & 0.357 & 0.435 \\
\hline
\end{tabular}

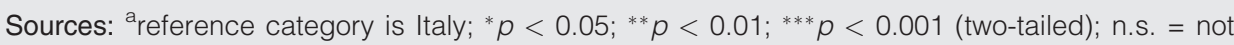
supported 
$p=0.000)$, "socializing" ( $\beta=0.073 ; p=0.011)$ and "discovery" $(\beta=0.177 ; p=0.000)$. Therefore, $\mathrm{H1}, \mathrm{H} 4$ and $\mathrm{H} 6$ were fully supported. As proposed, "recognition" was negatively related to hiking satisfaction ( $\beta=-0.079 ; p=0.011)$, and therefore, $\mathrm{H} 2$ was also fully supported. No effects were observed for "challenge" and "creativity," and therefore, $H 3$ and H6 were rejected. In addition, experience levels were found to significantly affect hiking satisfaction ( $\beta=0.331 ; p=0.000$ ), showing that less experienced hikers achieve lower levels of satisfaction than more experienced hikers Figure 1.

\section{Discussion}

Previous research showed that outdoor activities provide a vital contribution to improve wellbeing and health (Laesser, 2011; Han et al., 2020). This paper focused on the SAMsatisfaction relationship and highlighted the role of "relaxation," "discovery" and "socializing" for satisfaction in the soft adventure context (Table 4). In line with previous research on well-being (Kim et al., 2015), these findings underline that hiking as a soft adventure activity can contribute to the pursuit of well-being by securing the satisfaction of mountain hikers.

Previous adventure literature emphasized the importance of relaxation and alienation from everyday life (Caber and Albayrak, 2016; Den Breejen, 2007). This paper found the importance of relaxation as a major motivating factor in the hiking context. An interviewee described the experience of relaxation in the following way:

As soon as you hike toward the summit, you get other thoughts and you don't really think about everyday life anymore. You enter a world of your own, where there's just you and the view and the mountains. (Int. 14, 78)

This supports Vidon (2019), showing that alienation from everyday life is supported by remote and rural areas that support introspection and grounding. While relaxation emerged as an important factor in the quantitative phase, the interviewees confirmed this by perceiving hiking as a relaxing activity. As a result, we confirmed previous literature showing that hiking represents a balanced and mostly restorative way to experience nature (Rantala et al., 2018; Pomfret, 2006). Additionally, the findings confirm that the natural environment represents a motivation factor for outdoor sports activities (Ewert, 1985; Pomfret and Bramwell, 2016; Muhar et al., 2007; Caber and Albayrak, 2016). Although in the quantitative analysis, environment-related aspects such as "environment" and

\section{Figure 1 * $p<0.05 ;{ }^{* *} p<0.01 ;{ }^{* * *} p<0.001$ (two-tailed); n.s. = not supported; Figure} adapted from Kulp and Grandstaff (2019)

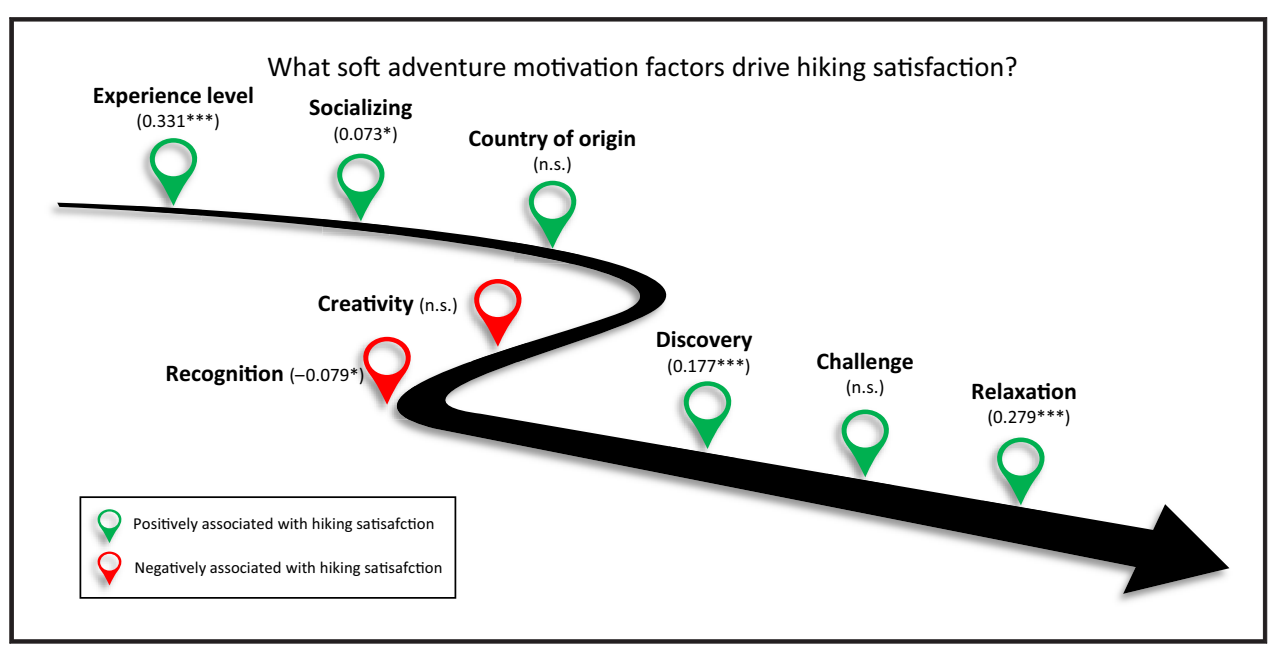

VOL. 76 NO. $22021 \mid$ TOURISM REVIEW $\mid$ PAGE 481 
"discovery" were synthesized in the "discovery" factor, the interviewees noted the importance of nature experiences and being outdoors. For example, the interviewees mentioned:

I like nature, I love the mountains [...] and I am more fascinated by the mountains than by the sea. (Int. 09, 63)

Thus, we agree with Giddy and Webb (2017) showing that the natural environment plays a vital role in nature-based adventure tourism. While indeed, many interviewees affirmed the role of experiencing nature, the interviews also emphasized the role of social factors for hiking. An interviewee explained:

I go hiking to experience nature and get some fresh air. Of course, fitness also plays a role, but hiking always has a social aspect. Being out with friends, sharing experiences and having a good atmosphere. (Int. 11, 49).

The quantitative findings found that mountain hikers seek to discover new things and places but are less motivated by challenging environments (Table 3). In the qualitative phase, we found that challenge and risk plays a minor role for mountain hikers. This was reinforced when interviewees where asked about their feelings related to competition or "citius, altius and forties." In this context, an interviewee explained:

This is becoming less and less important! It used to be like that, especially when we were on the trail together. Then competition plays a role, but otherwise, I am trying to enjoy nature and not always checking my watch. I really try to avoid that. (Int. 10, 66)

Consequently, for mountain hikers, it is essential to discover something new, to experience the (natural) scenery and to onboard adventures that fit the abilities and knowledge level. In this context, Olafsdottir (2013) argues that the positive effects of nature and environment represent a relational outcome that emerges from personal contributions and the performance of the environment. This was also stated by our interviewees, who distinguished between individual and external factors that led to satisfaction. Individual factors include the right amount of effort and not only experiencing physical difficulties, while external factors related to weather conditions, well-maintained trails, the novelty of the hike but also other services, such as hospitality at huts.

This study also adds to previous literature (Ewert, 1985; Ewert et al., 2013) by highlighting the adverse effects of "recognition." In particular, the findings show that recognition rates lower than other factors (Table 3 ) and the regression analysis confirmed the assumed negative relationship between "recognition" and satisfaction (Table 4). While external rewards and appreciation by others were found to increase satisfaction, in the context of more demanding and challenging outdoor activities (Albayrak and Caber, 2018; Caber and Albayrak, 2016), we found the adverse effects. The qualitative data also suggests in this light that soft adventure is not about belonging to a specific group, but more about belonging and immersing in nature, social contacts and the activity. In this context, interviewees highlighted not only the visual importance of nature and landscape but also the sounds and feelings. Interviewees explained that they wanted to be fully immersed in the environment and frequently spoke of its pleasure and rewards. The following statement of an interviewee expresses these feelings particularly well:

When I go hiking, I always have special feelings. On the one hand, there is this peace and silence, but sometimes you also feel the storm on your face and also environmental influences such as the sun are stronger than in the valley. When hiking, you always have to look ahead not to stumble. So you have to be concentrated, but in another form - a slower form. I always feel this as a certain reset in my head and I can think of things that are not related to my job and that is simply liberating. When you sit down and feel the sun on your skin, at that moment, you know that you don't need anything else to be happy. (Int. 1, 180) 
Additionally, previous literature frequently discussed the flow concept (Csikszentmihalyi, 1990; Wöran and Arnberger, 2012; Løvoll, 2019), which is defined as "a psychological state in which the person feels simultaneously cognitively efficient, motivated and happy" (Moneta and Csikszentmihalyi, 1996, p. 277). Although this research was not primarily about flow, the findings suggest several insights. In the hard adventure context, flow typically occurs when the faced challenges fit the skills (Csikszentmihalyi, 1990), while in the soft adventure context it results from changing terrains that provide challenges as summarized by Wöran and Arnberger (2012). However, the findings of this study do not confirm that challenge acts as a predictor of satisfaction (Table 4) and thereby we support previous studies, indicating that flow in the soft adventure context is likely to emerge from other factors such as immersion (Løvoll, 2019), pleasing landscapes (Wöran and Arnberger, 2012) or longer durations (Den Breejen, 2007).

Finally, the findings on experience levels also add to Wöran and Arnberger (2012), who found that increasing specialization positively affects flow experiences. In this study, the effects of experience levels diminished for highly skilled hikers, but it was found that lessskilled hikers tend to achieve lower levels of satisfaction (Table 4). This is in line with earlier research, which confirmed a positive relationship between increasing experience levels and the likeliness of more positive outcomes (Creyer et al., 2003).

\section{Conclusions and implications}

Hiking represents a soft adventure activity that distinguishes from the well researched hard adventure context (Pomfret, 2011). This paper aimed at a deeper understanding of mountain hikers' soft adventures by exploring underlying motivations, experiences and satisfaction. This is highly important, as mountain hiking accounts for a significant share of the nature-based tourism summer demand in mountain regions (Tirol Werbung, 2018; Mehmetoglu and Normann, 2013). Using a concurrent mixed method design (Teddlie and $\mathrm{Yu}, 2007)$, we provide more robust interpretations and thicker descriptions of our quantitative findings, which highlighted six SAM factors - "relax," "recognition," "challenge," "socializing," "creativity" and "discovery" (Table 3). We found that "relaxation," "discovery" and "socializing" contribute positively to satisfaction, while "recognition" was found to have an adverse effect (Table 4). Additionally, considering hikers' individual experience levels in the regression model showed that less experienced hikers tend to achieve less satisfactory outcomes. The interviews characterized hiking as a recreational activity and yet "challenge" was not a central finding, as most interviewees associated it with multisensory experiences leading to deep immersion in natural settings or social relationships.

Finally, this paper has several important implications for destinations and service providers. Most importantly, understanding motivations will help in designing appropriate experiences for tourists (Dodds, 2019). For example, the findings underline the importance of "relaxation," and thus, destination management organizations (DMO) need to emphasize the balancing potential and the benefits of hiking for physical and mental well-being (Rodrigues et al., 2010; Nordbø and Prebensen, 2015; Wolf and Wohlfart, 2014), in contrast to risk/fear/thrill like in the hard adventure context (Schlegelmilch and Ollenburg, 2013). This can be done by focusing on hedonic product features, such as pleasurable experiences and establishing multisensory adventures through e.g. the use of virtual reality in online communication.

Furthermore, the findings highlighted that social factors motivate the desire to hike. As many destinations in the European Alps focus on attracting families in the summer season (Tirol Werbung, 2018), the image of hiking as a shared social experience in a healthy mountain environment should be promoted. Additionally, hiking is a modern and trendy outdoor activity and although the findings show adverse effects for "recognition," it is important to acknowledge that the sharing of experiences and pictures on social media and rating platforms affects destinations and providers. Therefore, strategies on how to handle and direct social media activities are of utmost importance. 


\subsection{Future research and limitations}

This study leads to several recommendations for future research. It needs to shed more light on the experiences that occur during nature-based soft adventure activities (Løvoll, 2019). This will provide in-depth insights into narratives that characterize soft adventure experiences and help to progress the understanding of soft adventures. More empirical research is necessary to account for the consumption experience, individual characteristics of tourists (Teeroovengadum, 2019) and destination-related specifics and attributes. Therefore, destination-based segmentation profiles and comparisons are necessary to determine market strategies for destinations with different resource endowments. In contrast to previous studies (Atchley et al., 2012), this study has been unable to show the significant role that creativity has for mountain hikers (Table 4). As a result, future research needs to explore the potential impact of outdoor experiences such as hiking on creativity and problem-solving.

The findings of this analysis refer to several limitations. First, we were unable to control for the environment and the resulting responses, which may vary in time and space, in the quantitative phase. Sampling within the European Alps could introduce bias because of the region's strong and long tradition of mountain sports. Third, both samples are based on a relatively small number of participants, indicating the need for expanding samples and representations in future studies.

\section{References}

Abraham, A., Sommerhalder, K. and Abel, T. (2010), "Landscape and well-being: a scoping study on the health-promoting impact of outdoor environments", International Journal of Public Health, Vol. 55 No. 1, pp. 59-69.

Albayrak, T. and Caber, M. (2018), "A motivation-based segmentation of holiday tourists participating in white-water rafting”, Journal of Destination Management and Marketing, Vol. 9, pp. 64-71.

Atchley, R.A., Strayer, D.L. and Atchley, P. (2012), "Creativity in the wild. Improving creative reasoning through immersion in natural settings", PloS One, Vol. 7 No. 12, p. e51474.

Beard, J.G. and Ragheb, M.G. (1983), "Measuring leisure motivation", Journal of Leisure Research, Vol. 15 No. 3, pp. 219-228.

Beckman, E., Whaley, J.E. and Kim, Y.K. (2017), "Motivations and experiences of whitewater rafting tourists on the ocoee river, USA", International Journal of Tourism Research, Vol. 19 No. 2, pp. 257-267.

Beggs, B.A. and Elkins, D.J. (2010), "The influence of leisure motivation on leisure satisfaction", LARNetThe Cyber Journal of Applied Leisure and Recreation Research, July 2010, online first.

Brämer, R. (2008), "Profilstudie wandern '08. 1. Basismodul "wer wandert warum?", available at: www. wanderforschung.de/files/prostu0811249833531.pdf (accessed 30 May 2020).

Buckley, R. (2012), "Rush as a key motivation in skilled adventure tourism. Resolving the risk recreation paradox”, Tourism Management, Vol. 33 No. 4, pp. 961-970.

Caber, M. and Albayrak, T. (2016), "Push or pull? Identifying rock climbing tourists' motivations", Tourism Management, Vol. 55, pp. 74-84.

Chen, C.H. (2007), "Personality traits and their relationship to leisure motivation and leisure satisfaction in Southern Taiwan university students", in Fuss, F.K., Subic, A. and Ujihashi, S. (Eds), Impact of Technology on Sport II, Taylor \& Francis, Oxfordshire, pp. 889-896.

Chen, Y.-C., Li, R.H. and Chen, S.H. (2013), "Relationships among adolescents' leisure motivation, leisure involvement, and leisure satisfaction. A structural equation model", Social Indicators Research, Vol. 110 No. 3, pp. 1187-1199.

Chhetri, P., Arrowsmith, C. and Jackson, M. (2004), "Determining hiking experiences in nature-based tourist destinations", Tourism Management, Vol. 25 No. 1, pp. 31-43.

Chiang, C.-F., Jang, S., Canter, D. and Prince, B. (2008), "An expectancy theory model for hotel employee motivation: examining the moderating role of communication satisfaction", International Journal of Hospitality \& Tourism Administration, Vol. 9 No. 4, pp. 327-351. 
Crandall, R. (1980), "Motivations for leisure", Journal of Leisure Research, Vol. 12, pp. 45-54.

Creswell, J.W. and Plano Clark, V.L. (2011), Designing and Conducting Mixed Methods Research, 2nd ed., Sage, Los Angeles, London, New Delhi, Singapore, Washington, DC.

Creyer, E., Ross, W. and Evers, D. (2003), "Risky recreation: an exploration of factors influencing the likelihood of participation and the effects of experience", Leisure Studies, Vol. 22 No. 3, pp. 239-253.

Csikszentmihalyi, M. (1990), Flow: The Psychology of Optimal Experience, Harper and Row, New York, NY.

Dann, G.M.S. (1977), "Anomie, ego-enhancement and tourism”, Annals of Tourism Research, Vol. 4 No. 4, pp. 184-194.

Den Breejen, L. (2007), "The experiences of long distance walking: a case study of the west highland way in Scotland", Tourism Management, Vol. 28 No. 6, pp. 1417-1427.

Dodds, R. (2019), "The tourist experience life cycle: a perspective article", Tourism Review, Vol. 75 No. 1, pp. 216-220.

Dolnicar, S. (2004), "Beyond 'commonsense segmentation': a systematics of segmentation approaches in tourism", Journal of Travel Research, Vol. 42 No. 3, pp. 244-250.

Doyle, L., Brady, A.M. and Byrne, G. (2009), "An overview of mixed methods research", Journal of Research in Nursing, Vol. 14 No. 2, pp. 175-185.

Duda, J. and Nicholls, J. (1992), "Dimensions of achievement motivation in schoolwork and sport", Journal of Educational Psychology, Vol. 84 No. 3, pp. 290-299.

Eilzer, C. and Harms, T. (2019), "Wandern im urlaub. Stand der marktforschung und deutschlandweite repräsentative ergebnisse", in Quack, H.D., Dembowski, N. and Müller, D. (Eds), Wandern Als Ware: Zwischen Natur Und Kommerzialisierung, Erich Schmidt Verlag, Berlin, pp. 33-54.

Ewert, A. (1985), "Why people climb. The relationship of participant motives and experience level to mountaineering", Journal of Leisure Research, Vol. 17 No. 3, pp. 241-250.

Ewert, A., Gilbertson, K., Luo, Y.C. and Voight, A. (2013), "Beyond 'because it's there'”, Journal of Leisure Research, Vol. 45 No. 1, pp. 91-111.

Fluker, M.R. and Turner, L.W. (2000), "Needs, motivations, and expectations of a commercial whitewater rafting experience", Journal of Travel Research, Vol. 38 No. 4, pp. 380-389.

Giddy, J.K. and Webb, N.L. (2017), "The influence of the environment on adventure tourism. From motivations to experiences", Current Issues in Tourism, Vol. 5 No. 12, pp. 1-15.

Gould, J., Moore, D., McGuire, F. and Stebbins, R. (2008), "Development of the serious leisure inventory and measure", Journal of Leisure Research, Vol. 40 No. 1, pp. 47-68.

Gross, S. and Sand, M. (2019), "Adventure tourism: a perspective paper", Tourism Review, Vol. 75 No. 1, pp. 153-157.

Hair, J.F. (2010), Multivariate Data Analysis, 7th ed., Pearson Prentice Hall, Upper Saddle River, NJ.

Hallmann, K., Feiler, S. and Breuer, C. (2012), "Sport motivation as driver for segmenting sport tourists in coastal regions", Tourism Review, Vol. 67 No. 2, pp. 4-12.

Han, H., Lho, L.H., Al-Ansi, A. and Yu, J. (2020), "Cycling tourism. A perspective article", Tourism Review, Vol. 75 No. 1, pp. 162-164.

Kastenholz, E. and Rodriguez, A. (2007), "Discussing the potential benefits of hiking tourism in Portugal", Anatolia, Vol. 18 No. 1, pp. 5-21.

Kerr, J.H. and Mackenzie, S.H. (2012), "Multiple motives for participating in adventure sports", Psychology of Sport and Exercise, Vol. 13 No. 5, pp. 649-657.

Kiatkawsin, K. and Han, H. (2017), "Young travelers' intention to behave pro-environmentally: merging the value-belief-norm theory and the expectancy theory", Tourism Management, Vol. 59, pp. 76-88.

Kim, H., Lee, S., Uysal, M., Kim, J. and Ahn, K. (2015), "Nature-based tourism: motivation and subjective well-being", Journal of Travel \& Tourism Marketing, Vol. 32, pp. S76-S96.

King, N., Horrocks, C. and Brooks, J.M. (2019), Interviews in Qualitative Research, 2nd ed., Sage, Los Angeles, London, New Delhi, Singapore, Washington, DC, Melbourne. 
Kozak, M. (2001), "Repeaters' behavior at two distinct destinations", Annals of Tourism Research, Vol. 28 No. 3, pp. 784-807.

Kulp, A. and Grandstaff, M. (2019), "Visualizing regression results for non-statistics audiences", available at: www.airweb.org/article/2019/04/17/visualizing-regression-results-for-non-statistics-audiences (accessed 3 June 2020).

Laesser, C. (2011), "Health travel motivation and activities: insights from a mature market - Switzerland", Tourism Review, Vol. 66 Nos 1/2, pp. 83-89.

Lee, C.K., Lee, Y.K. and Wicks, B.E. (2004), "Segmentation of festival motivation by nationality and satisfaction", Tourism Management, Vol. 25 No. 1, pp. 61-70.

Leri, I. and Theodoridis, P. (2019), "The effects of the winery visitor experience on emotions, satisfaction and on post-visit behaviour intentions", Tourism Review, Vol. 74 No. 3, pp. 480-502.

Lounsbury, J.W. and Polik, J.R. (1992), "Leisure needs and vacation satisfaction", Leisure Sciences, Vol. 14 No. 2, pp. 105-119

Løvoll, H.S. (2019), "The inner feeling of glacier hiking. An exploratory study of "immersion" as it relates to flow, hedonia and eudaimonia", Scandinavian Journal of Hospitality and Tourism, Vol. 29, pp. 1-17.

Lyng, S. (1990), "Edgework. A social psychological analysis of voluntary risk taking", The American Journal of Sociology, Vol. 95 No. 4, pp. 851-886.

MAXQDA (2020), "All-in-one qualitative and mixed methods data analysis tool", available at: www. maxqda.com/ (accessed 14 January 2020).

Mehmetoglu, M. and Normann, $\varnothing$. (2013), "The link between travel motives and activities in nature-based tourism", Tourism Review, Vol. 68 No. 2, pp. 3-13.

Moneta, G.B. and Csikszentmihalyi, M. (1996), "The effect of perceived challenges and skills on the quality of subjective experience", Journal of Personality, Vol. 64 No. 2, pp. 275-310.

Muhar, A., Schauppenlehner, T., Brandenburg, C. and Arnberger, A. (2007), "Alpine summer tourism. The mountaineers' perspective and consequences for tourism strategies in Austria", Forest Snow and Landscape Research, Vol. 81 Nos 1/2, pp. 7-17.

Müller, D. (2019), "Regionalwirtschaftliche effekte des wanderns", in Quack, H.D., Dembowski, N. and Müller, D. (Eds), Wandern Als Ware: Zwischen Natur Und Kommerzialisierung, Erich Schmidt Verlag, Berlin, pp. 54-70.

Nordbø, I. and Prebensen, N.K. (2015), "Hiking as mental and physical experience", in Chen, J.S. (Ed.), Advances in Hospitality and Leisure, Advances in Hospitality and Leisure, Vol. 11, Emerald Group Publishing Limited, pp. 169-186.

Oh, H. (1999), "Service quality, customer satisfaction, and customer value. A holistic perspective", International Journal of Hospitality Management, Vol. 18 No. 1, pp. 67-82.

Olafsdottir, G. (2013), “... sometimes you've just got to get away: on trekking holidays and their therapeutic effect", Tourist Studies, Vol. 13 No. 2, pp. 209-231.

Onwuegbuzie, A.J. and Teddlie, C. (2003), "A framework for analyzing data in mixed methods research", in Tashakkori, A. and Teddlie, C. (Eds), Sage Handbook of Mix-Methods in Social and Behavioral Research, 2nd ed., Sage, Thousand Oaks, CA, pp. 351-384.

Ortner, S. Peters, M. and Bichler, B.F. (2020), "Eine Marktsegmentierung des alpinen Wanderer. Endbericht für den Fördergeber Land Tirol", available at: https://irp-cdn.multiscreensite.com/919d856e/ files/uploaded/Endbericht_LFUI_LOLA_AlpinesWandern.pdf (accessed 30 May 2020).

Park, D.B. and Yoon, Y.S. (2009), "Segmentation by motivation in rural tourism: a Korean case study", Tourism Management, Vol. 30 No. 1, pp. 99-108.

Podsakoff, P.M., MacKenzie, S.B., Lee, J.Y. and Podsakoff, N.P. (2003), "Common method biases in behavioral research: a critical review of the literature and recommended remedies", The Journal of Applied Psychology, Vol. 88 No. 5, pp. 879-903.

Pomfret, G. (2006), "Mountaineering adventure tourists. A conceptual framework for research", Tourism Management, Vol. 27 No. 1, pp. 113-123.

Pomfret, G. (2011), "Package mountaineer tourists holidaying in the french alps. An evaluation of key influences encouraging their participation", Tourism Management, Vol. 32 No. 3, pp. 501-510. 
Pomfret, G. and Bramwell, B. (2016), "The characteristics and motivational decisions of outdoor adventure tourists. A review and analysis", Current Issues in Tourism, Vol. 19 No. 14, pp. 1447-1478.

Rantala, O., Hallikainen, V., Ilola, H. and Tuulentie, S. (2018), "The softening of adventure tourism", Scandinavian Journal of Hospitality and Tourism, Vol. 18 No. 4, pp. 343-361.

Raya, M.J., Martínez-Garcia, E. and Celma, D. (2018), "Economic and social yield of investing in hiking tourism. The case of Berguedà, Spain”, Journal of Travel \& Tourism Marketing, Vol. 35 No. 2, pp. 148-161.

Rodrigues, A., Kastenholz, E. and Rodrigues, A. (2010), "Hiking as a relevant wellness activity - results of an exploratory study of hiking tourists in Portugal applied to a rural tourism project", Journal of Vacation Marketing, Vol. 16 No. 4, pp. 331-343.

Ryan, C. and Glendon, I. (1998), "Application of leisure motivation scale to tourism", Annals of Tourism Research, Vol. 25 No. 1, pp. 169-184.

Sand, M., May, C. and Gross, S. (2019), "Prescribing adventure - analysing the benefits of adventure for health and well-being", in ATRA (Ed.), 7th International Adventure Conference Book of Abstracts of the International Conference in Dumfries \& Galloway, Fort William, pp. 4-5.

Schlegelmilch, F. and Ollenburg, C. (2013), "Marketing the adventure. Utilizing the aspects of risk/fear/ thrill to target the youth traveller segment", Tourism Review, Vol. 68 No. 3, pp. 44-54.

Schumacher, K. (2016), Wandern Als Erlebnis: Merkmale - Wahrnehmung - Analyse, Erich Schmidt Verlag, Berlin.

Teddlie, C. and Yu, F. (2007), "Mixed methods sampling", Journal of Mixed Methods Research, Vol. 1 No. 1, pp. 77-100.

Teeroovengadum, V. (2019), "Environmental identity and ecotourism behaviours. Examination of the direct and indirect effects", Tourism Review, Vol. 74 No. 2, pp. 280-292.

Thomas, D.W. and Butts, F.B. (1997), "Assessing leisure motivators and satisfaction of international elderhostel participants", Journal of Travel \& Tourism Marketing, Vol. 7 No. 1, pp. 31-38.

Thongdejsri, M. and Nitivattananon, V. (2019), "Assessing impacts of implementing low-carbon tourism program for sustainable tourism in a world heritage city", Tourism Review, Vol. 74 No. 2, pp. 216-234.

Tirol Werbung (2018), "Topic study 'hiking' and vacationer typologies 2017", available at: www.alp-net. eu/wp-content/uploads/2018/10/Topic-Study-Hiking-and-Vacationer-Typologies-2017_AlpNet.pdf (accessed 30 August 2019).

UNWTO (2019), Walking Tourism: Promoting Regional Development, UNWTO, Madrid.

Uysal, M. and Jurowski, C. (1994), "Testing the push and pull factors", Annals of Tourism Research, Vol. 21 No. 4, pp. 844-846.

Varley, P. and Semple, T. (2015), "Nordic slow adventure. Explorations in time and nature", Scandinavian Journal of Hospitality and Tourism, Vol. 15 Nos 1/2, pp. 73-90.

Vidon, E.S. (2019), "Why wilderness? Alienation, authenticity, and nature", Tourist Studies, Vol. 19 No. 1, pp. 3-22.

Vroom, V.H. (1964), Work and Motivation, Wiley, New York, NY.

Walle, A.H. (1997), "Pursuing risk or insight", Annals of Tourism Research, Vol. 24 No. 2, pp. 265-282.

Wall-Reinius, S. and Bäck, L. (2011), "Changes in visitor demand. Inter-year comparisons of Swedish hikers' characteristics, preferences and experiences", Scandinavian Journal of Hospitality and Tourism, Vol. 11, pp. 38-53.

Wanderhotels (2019), "The best hiking hotels in the alps", available at: https://issuu.com/wanderhotels/ docs/wh_hotelguide_2019_fertig (accessed 20 March 2019).

Watson, T.J. (1997), "Theorizing managerial work. A pragmatic pluralist appraoch to interdisciplinary research", British Journal of Management, Vol. 5, pp. 3-8.

Weber, K. (2001), "Outdoor adventure tourism", Annals of Tourism Research, Vol. 28 No. 2, pp. 360-377.

Wolf, I.D. and Wohlfart, T. (2014), "Walking, hiking and running in parks: a multidisciplinary assessment of health and well-being benefits", Landscape and Urban Planning, Vol. 130, pp. 89-103.

Wöran, B. and Arnberger, A. (2012), "Exploring relationships between recreation specialization, restorative environments and Mountain hikers' flow experience", Leisure Sciences, Vol. 34 No. 2, pp. 95-114. 


\section{Appendix}

\section{Table A1 Overview interviewees}

\begin{tabular}{lllll}
\hline Interviewee & Gender & Age & Age & Experiencelevel \\
\hline Interviewee 1 & Male & 1984 & 36 & Highly experienced \\
Interviewee 2 & Female & 1996 & 24 & Medium experienced \\
Interviewee 3 & Female & 1996 & 24 & Medium experienced \\
Interviewee 4 & Female & 1977 & 43 & Medium experienced \\
Interviewee 5 & Female & 1986 & 34 & Less experienced \\
Interviewee 6 & Female & 1966 & 54 & Less experienced \\
Interviewee 7 & Male & 1979 & 41 & Medium experienced \\
Interviewee 8 & Female & 1979 & 41 & Medium experienced \\
Interviewee 9 & Female & 1975 & 45 & Medium experienced \\
Interviewee 10 & Female & 1984 & 36 & Medium experienced \\
Interviewee 11 & Female & 1993 & 27 & Less experienced \\
Interviewee 12 & Male & 1995 & 25 & Medium experienced \\
Interviewee 13 & Male & 1973 & 47 & Medium experienced \\
Interviewee 14 & Male & 1998 & 22 & Medium experienced
\end{tabular}

\section{About the authors}

Bernhard Fabian Bichler is a Pre Doc University Assistant at the Department of Strategic Management, Marketing and Tourism at the University of Innsbruck (Austria). He graduated with a degree in International Business Studies and Geography from the University of Innsbruck, including studies abroad at the University of Navarra (Spain). He is a leading member of the interdisciplinary doctoral program "Tourism and Leisure in Mountain Regions." His research interests are entrepreneurship and destination management with a focus on the governance of touristic areas. Bernhard Fabian Bichler is the corresponding author and can be contacted at: bernhard.bichler@uibk.ac.at

Mike Peters is a Professor at the Department of Strategic Management, Marketing and Tourism at the Faculty of Business and Management, University of Innsbruck. His research interests include small business development, family businesses in tourism, destination management, entrepreneurship and innovation.

For instructions on how to order reprints of this article, please visit our website: www.emeraldgrouppublishing.com/licensing/reprints.htm Or contact us for further details: permissions@emeraldinsight.com 